\title{
Effect of Soybean Fortified Porridges on the Nutritional Status of Pre-school Children 3-5Years Old from Western Kenya
}

\author{
Amos Kipkemoi Ronoh ${ }^{1}$, Gertrude Mercy Were ${ }^{1}$, Florence Wakhu-Wamunga ${ }^{1}$, \\ John Brian Wamunga ${ }^{2}$ \\ ${ }^{1}$ School of Agriculture and Biotechnology, Department of Family and Consumer Sciences, University of Eldoret, Eldoret, Kenya \\ ${ }^{2}$ School of Applied Human Sciences, Department of Food, Nutrition and Dietetics, Kenyatta University, Nairobi, Kenya
}

\section{Email address:}

ronoamos00@gmail.com (A. K. Ronoh)

\section{To cite this article:}

Amos Kipkemoi Ronoh, Gertrude Mercy Were, Florence Wakhu-Wamunga, John Brian Wamunga. Effect of Soybean Fortified Porridges on the Nutritional Status of Pre-school Children 3-5Years Old from Western Kenya Journal of Food and Nutrition Sciences.

Vol. 5, No. 4, 2017, pp. 155-161. doi: 10.11648/j.jfns.20170504.13

Received: May 15, 2017; Accepted: May 23, 2017; Published: July 12, 2017

\begin{abstract}
Protein and energy malnutrition continues to be a global health problem particularly in Sub-Saharan Africa. This is attributed to high levels of poverty where most households cannot afford animal source proteins. Cheaper and sustainable legumes can be used to address this. To evaluate the effect of soybean fortified porridges on the nutritional status of children in early childhood development centre at Mateka Primary School, Bungoma County. A longitudinal survey and Complete Randomized Design experimental design were employed in this study. The first porridge formulation was made of maize and soybean in the ratio 75:25, the second maize, and sorghum soybeans in the ratio 50:25:25 and the third formulation 100\% maize. The three porridges were randomly allocated to three groups of the children and were fed for a period of six months with approximately $300 \mathrm{ml}$ of the porridge. Nutritional assessment was done at baseline, and every month for six months at the ninth month. At baseline, $30 \%, 6.7 \%$ and $10.8 \%$ of the children were stunted, wasted and underweight respectively. At the end of the feeding trial, there was significant $(\mathrm{p}<0.05)$ reduction in the levels of underweight $(47.27 \%)$ and wasting $(44.23 \%)$ in the soybean fortified porridge groups. The group fed on maize-soybean blend and maize-sorghum-soybean blend gained $1.77 \mathrm{kgs}$ and $0.62 \mathrm{kgs}$ respectively. In conclusion, soybean fortified porridges improved the nutritional status of the children. It is recommended that awareness of the nutritional benefits of soybean should be raised to increase its adoption in the households and also it will be valuable schools with feeding programs to introduce corn-soy blends or products as part of school meals.
\end{abstract}

Keywords: Soybean Fortification, Nutritional Status, Pre-school Children

\section{Introduction}

Malnutrition is a serious global health problem brought about by inequalities in the economic systems and social injustices resulting in incidences of underweight and stunting among children [1]. In 2014 alone, 6.3 million children were reported globally to have died of malnutrition by the World Health Education Service [2]. Protein Energy Malnutrition (PEM) is considered the worst form of malnutrition associated with lack of energy and proteins and a major deficiency disease that affects children in Asia and other developing countries [3].

Increasing PEM levels in Sub-Saharan Africa and Asia is attributed to high levels of poverty [4] such that most families in these countries cannot afford to include animal protein in their diets owed to their high cost. With this regard, these people consume plant based diets as they are cheaper, though their quality is poorer compared to animal proteins that contain all indispensable amino acids and have high digestibility [5].

Since legumes and cereal grains are the most important sources of plant proteins in the context of human protein nutrition, there is need to utilize them as an alternative source of cheap, high quality protein for people in the developing countries. Furthermore it has been documented that compositing legume proteins with those from cereal and root 
crops has a complementation effect producing complete and well balanced amino acid profiles that meet human physiological requirements [6].

Soybean (Glycine max (L) Merril) among legumes, is recognized for its high nutritional value as it contains about $40 \%$ protein, $23 \%$ carbohydrate, $20 \%$ oil and, $4 \%$ minerals [7]. It has a protein content twice that of pulses, groundnuts, meat and fish. Soy protein contains eight essential amino acids, and is superior to other plant proteins. Soybean is an excellent source of mineral elements such as potassium, and vitamins such as riboflavin, choline, thiamine and pantothenic acid and high energy due to its oil content [8]. It is a cheap source of protein and a sustainable protein that can be used to alleviate malnutrition in developing countries through complementation of cereals to boost their protein and amino acid content [9]. Cereals such as maize and sorghum provide an easy vehicle for delivering protein in the diet as they are the most consumed staples developing countries.

The use of corn-soy blends (CSB) has been promoted as one of the sustainable ways of alleviating PEM in developing countries [10]. In Western Kenya where the levels of PEM are high among pre-school children, soybean has been introduced in an effort to reduce the prevalence. These soybean fortified flours should be tested whether they can improve the nutritional status of the children.

According to the Kenya County Early Childhood Education Bill (2014) [11], every County Education Board should carry out feeding programs in early education centres in areas where children are affected by malnutrition or have special nutritional needs. The Act further says that the feeding programs should provide adequate and nutritious foods based on the physiological needs and the regional demands. Children in feeding centres in Bungoma County are fed on the porridges made from starchy staples and often lack proteins in them. This shows that these porridges do not meet the protein needs of the growing child. Therefore this study sought to evaluate the effect of soybean fortified porridges on the nutritional status of children the 3-5 years old.

\section{Materials and Methods}

\subsection{Research Design and Sampling Procedures}

A longitudinal survey was used for this study. The longitudinal survey was used to gather information on sociodemographic information of the households and data on nutrient adequacy of the children. Randomization was used in the assignment of the porridges to the children using a Completely Randomized Design (CRD). The target population comprised of all children in Early Childhood Education (E. C. D) (Baby, Middle and Top) classes aged 3-5 years attending Mateka Primary school in Bungoma County. 100 children were randomly selected from the ECD classes. The children were fed on approximately $100 \mathrm{~g}$ of the soybean fortified porridges for a period of six months. Anthropometric measurements were taken each month for the six months and also at the ninth month.

\subsection{Pre-treatment of the Ingredients}

Maize (Zea mays), soybeans (Glycine max) and sorghum (Sorghum bicolor) were used as the ingredients to composite the flours. These ingredients were bought from Eldoret Municipal market. Sugar was commercially available in Eldoret. The soybean grains were sorted to remove those that are diseased, those with damaged seed coats and those infested by pests; they were then be winnowed to manually separate the chaff and the grains. They were then be roasted for 20 minutes in the oven at $180^{\circ} \mathrm{C}$, while stirring occasionally, to reduce the levels of antinutrient factors, inactivate lipoxygenase enzymes and improve flavor. All the grains were then cooled at room temperature. All the grains were later milled separately using a commercial hammer mill (Powerline ${ }^{\circledR}, \mathrm{BM}-35$, Kirloskar, India) in Eldoret, fitted with a $2.0 \mathrm{~mm}$ opening screen.

\subsection{Formulation of Flours}

The first formulation constituted maize, sorghum and soybean flours in the ratio 50:25:25 by weight. The second formulation constituted maize, and soybean flours in the ratio 75:25 respectively. This is according to World Health Organization recommendation of the ratio $3: 1$ of carbohydrates to proteins in supplementary foods. The third composite was made of $100 \%$ maize flour which was used as a control. The grains were mixed together in their respective compositions and then milled. They were then mixed to homogenize and then weighed into clear water-proof polythene bags in packages of $3 \mathrm{kgs}$ each, and each flour type well labeled with codes.

Table 1. Proximate composition of the flours ( $\mathrm{g} / 100 \mathrm{~g})$.

\begin{tabular}{|c|c|c|c|}
\hline Flours & $\begin{array}{l}\text { Maize } \\
\text { (MZ) }\end{array}$ & $\begin{array}{l}\text { Maize+soybean } \\
\text { (MS) }\end{array}$ & $\begin{array}{l}\text { Maize+sorghum+ } \\
\text { Soybean (SMS) }\end{array}$ \\
\hline Ash & 0.83 & 5.51 & 5.45 \\
\hline Moisture & 10.23 & 9.27 & 9.11 \\
\hline Oil & 4.29 & 11.30 & 11.45 \\
\hline Protein & 9.45 & 17.39 & 18.59 \\
\hline Carbohydrate $^{1}$ & 75.20 & 56.53 & 55.45 \\
\hline Energy $(\mathrm{Kj})^{2}$ & 1578.247 & 1662.638 & 1669.458 \\
\hline
\end{tabular}

${ }^{1}$ Calculated by the difference method [12] where $\%$ carbohydrates $=100-(\%$ fat $+\%$ moisture $+\%$ ash (minerals) $+\%$ protein)

${ }^{2}$ Calcualted by multiplying with Atwater's factor [12] where energy $(\mathrm{Kj})=$ $(\%$ carbohydrates $\times 16.736)+(\%$ protein $\times 16.736)+(\%$ oil $\times 37.656)$

\subsection{Administration of the Feeding Program}

At baseline, data on socio-demographic information, nutritional adequacy and nutritional status of the children were taken. The porridges were randomly assigned to the three classes. Preparation of the porridge was done according to [13] standard recipe for preparation of gruel. Each child received $300 \mathrm{ml}$ of the respective porridges every 10 o'clock in the morning, for five days in a week (Monday to Friday) for six months. At the $6^{\text {th }}$ month, the feeding program was terminated. Anthropometric measurements (weight, height 
and Mid Upper Arm Circumference) were taken every month for the six month and the final measurement done on the treatment children on the $9^{\text {th }}$ month. Anthropometric data were collected according procedures described by [14].

\subsection{Data Analysis}

ENA for SMART for Windows was used to analyze data on nutritional status of the children. Nutritional data was exported to Statistical Package Social Sciences to check for significant differences between the nutritional status of the children at baseline and the endline using ANOVA. A P value of $<0.05$ was considered statistically significant.

\subsection{Ethical Consideration}

Permission to carry out the research was sought from the National Commission for Science Technology and Innovation (NACOSTI) and the Institutional Research and Ethics Committee (IREC), Moi University. Written consent was sought from the parents of the children. Verbal consent was obtained from the children. Permission was obtained from the school administration before carrying out the survey and the feeding program in the school.

\section{Results and Discussion}

\subsection{Nutritional Status of the Children at Baseline}

Seventy percent $(70 \%)$ of the children were normal at baseline. According to the MUAC measurements, $75 \%$ of the children were normal at baseline, while $25 \%$ were wasted. Results further revealed that at baseline, the prevalence of underweight was $10.8 \%$. Underweight is a consequence of acute and chronic malnutrition. This value is higher than that reported in the Kenya Demographic Health Survey [15] in Western Kenya of $2.9 \%$ and almost similar to the national value on underweight prevalence of $11 \%$ [15]. The prevalence of wasting in this study was $6.7 \%$. This value is higher than national prevalence of $4 \%$ [15]. Studies in Western Kenya have reported almost similar values. A study by [16] reported a lower value of $5.9 \%$.

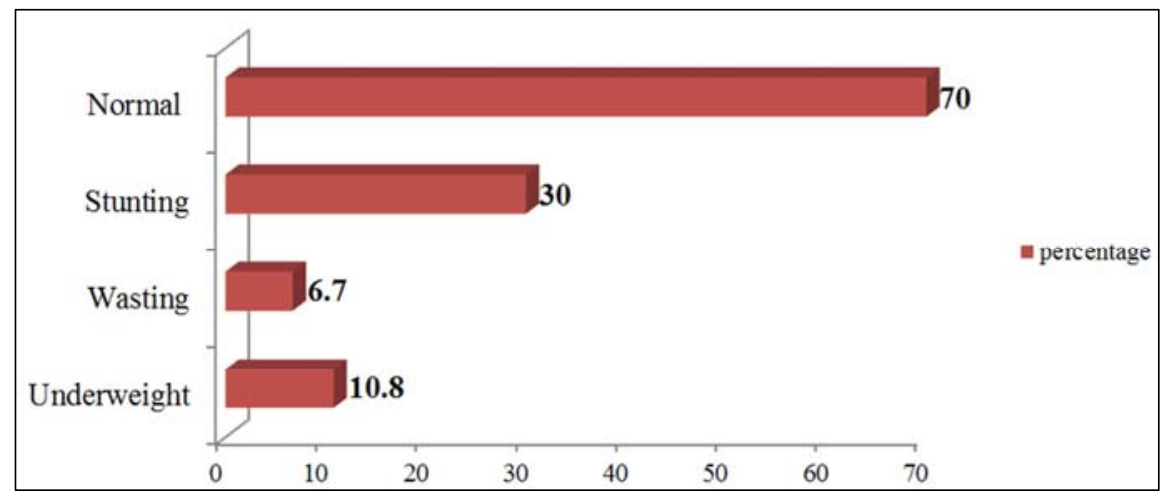

Figure 1. Nutritional status of the children at baseline.

The prevalence of stunting was $30 \%$. The prevalence of malnutrition reported in this study area was high. Stunting is a result of prolonged inadequate intake of food as well as diseases making young children to have a low height for age [17]. Stunting is associated with low cognitive development and increased morbidity in children under 5 years old [18]. The prevalence of stunting in the area is almost similar to that reported in Western Kenya in the Kenya Demographic Health Survey (KDHS) at 24.4\% [15] and [19] at 29.4\%. A study in Western Kenya among children 2-5 years old children in cassava consuming households concluded that this was the age when most of the children become stunted due to inadequate consumption of proteins in their diet [20]. However, this value is higher than the national prevalence of $26 \%$ [15]. The prevalence of stunting at this age group suggests that most of the households in the area are perennially food insecure and therefore the diets fed to the children might be inadequate to meet their physiological needs for growth.

\subsection{Prevalence of Underweight Between Baseline and 9 Months}

The prevalence of underweight in the experimental groups was $10.4 \%$ and $11.0 \%$ at the baseline for Soybean-Maize porridge group and sorghum-maize-soybean porridge group respectively. In the control group, the prevalence of underweight at baseline was $10.9 \%$ and this value decreased to $10.4 \%$ at the end of the feeding trial (Table 2).

Table 2. Prevalence of underweight between baseline, $6^{\text {th }}$ and $9^{\text {th }}$ month.

\begin{tabular}{|c|c|c|c|c|c|c|c|}
\hline \multirow{2}{*}{$\begin{array}{l}\text { Underweight } \\
\text { Experimental groups } \\
\end{array}$} & \multicolumn{3}{|c|}{ Before intervention (Baseline) } & \multicolumn{2}{|l|}{$6^{\text {th }}$ month } & \multicolumn{2}{|l|}{$9^{\text {th }}$ month } \\
\hline & SM group & SMS group & MZ group & SM group & SMS group & SM group & SMS group \\
\hline$<-2$ SD to $-3 \mathrm{SD}$ (Moderate) & 9.5 & 9.7 & 10.1 & 5.4 & 5.8 & 9.6 & 8.6 \\
\hline$<3 \mathrm{SD}$ (Severe) & 0.9 & 1.4 & 0.8 & 0 & 0 & 0.3 & 0.6 \\
\hline
\end{tabular}

$\mathrm{SM}=$ soybean + maize, $\mathrm{SMS}=$ sorghum + maize + soybean, $\mathrm{MZ}=$ maize only 
This study found that there was an increase in the weight of the children in the experimental group after feeding them with the soybean fortified porridges. The children who were fed on SM showed modest weight increase at each month when the measurements were taken. The highest value was recorded at the $6^{\text {th }}$ month for the MS group. The children fed on the sorghum-maize-soybean (SMS) mixture showed that that there was slowed increase in the weight gain of the children particularly at the beginning of the intervention. The children who were fed on the control porridge made from maize only showed slowed and stagnant weight throughout the study. This study showed that there was significant increase in the weight of the children fed on the experimental porridges $(p<0.05)$. On the other hand, children who were fed on the maize only porridge showed increased levels of underweight in the children. However, children who were fed on the SMS porridge showed that the rate of weight gain was low as compared to those that were fed on the SM even though the protein content of the latter porridge was higher. This could be attributed to the high anti-nutrient content in the SMS blend. Nutrient absorption from complementary foods of children may be limited by anti-nutrient factors such as phytic acid which is high in sorghum [19]. Phytic acid is a potent inhibitor of iron, zinc and calcium, which are key nutrients that are needed for growth and development of young children. Young children are also likely to be more sensitive to the effect of anti-nutrients, for example high levels of phytate, which impairs the absorption of several growth-limiting minerals, such as zinc [6]. For example, zinc is essential to growth, syntheses and maintenance of lean body mass in children [6]. Food analysis of soy-maizesorghum based Ready to Use Complementary Food (RUCF) used by [19] showed a high phytic acid content and a high phytic acid: iron molar ratio from the ingredients used. A study by [10] showed that the phytic acid mineral molar ratios observed for raw and extruded sorghum-maizesoybean products were higher than those preferred for adequate mineral absorption young children. Evidence has shown that removal of phytic acid from the food matrix using microbial phytase is associated with improved weight for Age (underweight) and decreased deficiencies of iron and zinc in young children [10].

Similar studies have shown that feeding of children with soybean fortified supplementary foods improves the weight of the children as well as reducing the levels of wasting an underweight in the study children [22-24].

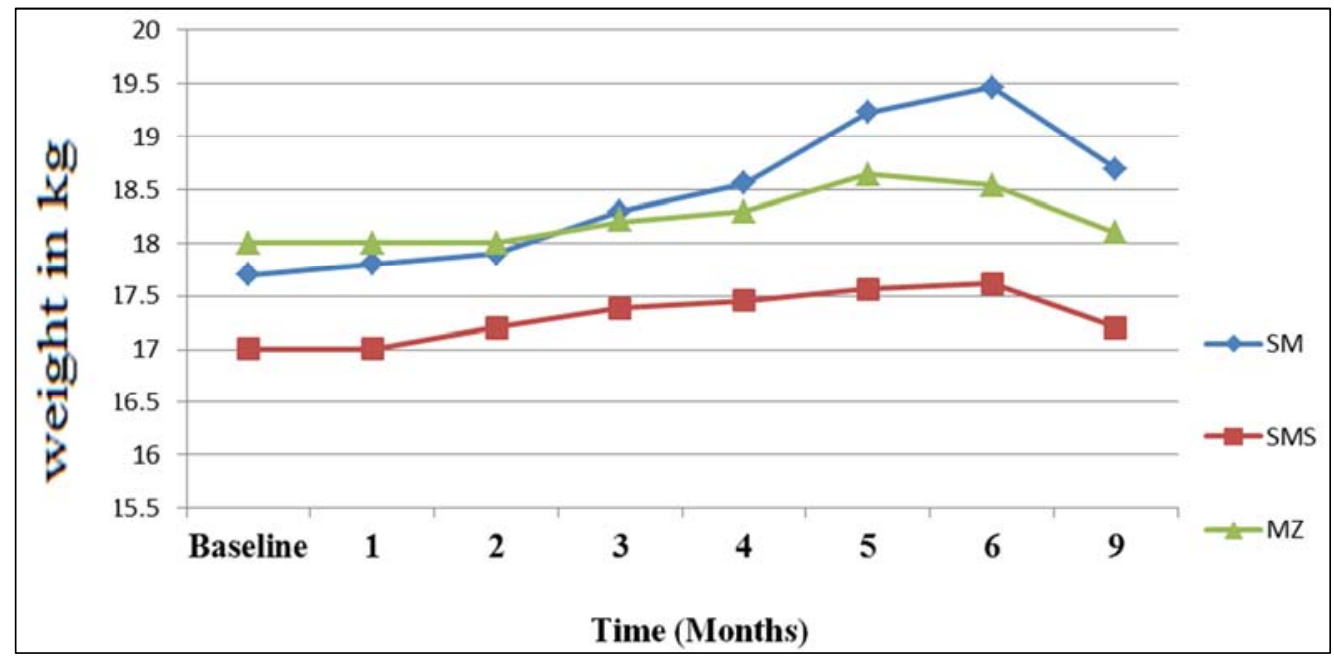

$\mathrm{SM}=$ soybean + maize, $\mathrm{SMS}=$ sorghum + maize + soybean, $\mathrm{MZ}=$ maize only

Figure 2. The trends in the weight changes in the children during the feeding trial.

\subsection{Prevalence of Wasting Between Baseline and 9 Months}

The prevalence of wasting among children in the experimental group was at $5.8 \%$ and $6.1 \%$ for CSB and the SMS groups respectively at baseline. After the feeding trial, these values decreased to $3.9 \%$ and $4.8 \%$ respectively for the SM and the SMS group respectively. On the other hand, the control group had a prevalence of $6.1 \%$ at baseline, and this value decreased to $4.8 \%$ by the end of the $6^{\text {th }}$ month. The value then increased to $5.8 \%$ at the end of the $9^{\text {th }}$ month when children had been withdrawn from the feeding trial. The changes in the wasting levels before and after the feeding trial were significant in both groups $(\mathrm{p}<0.05)$.

This study found that there was a significant reduction in the prevalence of underweight and wasting at the end of the feeding trial for children in the experimental group. The reduction in the prevalence in the malnutrition indices could be attributed to the increase in the quantity of lysine, an essential amino acid, in the diets of the children. Mutual complementation of cereals with legumes (Soybean) leads to a product with high amino acid profile. This is with reference to improvement in the content of the indispensable amino acid, lysine. [25] established that fortification of maize with soybean significantly improved the lysine content. This therefore shows that increase in the lysine content in the soybean fortified could have led to the improvement in the nutritional status of the children. [26] showed that the improvement in the lysine content of soybean fortified 
biscuits was adequate to meet the nutrient needs of children 2 years and 3-10 year old children.

On the other hand, the control group didn't show any significant changes in the wasting level. Consumption of food products made from maize flour, for example porridge has been implicated for etiology of malnutrition particularly among young children. A review by [27] showed that frequent consumption of Koko, a Ghanaian food prepared from maize flour, was implicated for protein and energy malnutrition in children. [28] revealed that frequent consumption of diets based on maize and cassava was positively correlated with the development of kwashiorkor among young children in the Democratic Republic of Congo. This can be attributed to the low nutritional value of maize. The protein quality of maize is poor, being low in lysine and tryptophan, which are the indispensable amino acids for growth of young children [7]. [25] showed that feeding of experimental rats with a diet from maize only neither led to significant weight gain or loss. This shows that there was stagnation in growth, and this might have been the case in this study. Furthermore, porridge prepared from maize has low energy density and is bulky.

The second reason for the improvement in the nutritional status of the children could be due to improved protein quality in the soybean fortified porridge. Complementation of cereals and legumes increase the protein quality of the flour blend. [25] showed that fortification of maize meal flour with soybean flour led to a significant improvement in the PDCAAS value from $53 \%$ in maize flour to $70 \%$ in the soybean fortified flour. PDCAAS is a WHO endorsed method for assessing the protein quality of a food. Foods with a PDCAAS of over $70 \%$ are recommended for ensuring growth in young children [6]. From the PDCASS value of the soybean fortified flours, it can be extrapolated that the porridge was able to support improvement in the nutritional status of the children.

Furthermore, the porridge supplemented the energy intakes of the children. The soybean fortified porridges provided 395 $\mathrm{Kcal} / 100 \mathrm{~g}$ to the diets of the children. Since the children were fed on approximately $300 \mathrm{ml}$ of the porridge every day, the contribution of the soybean fortified porridges was 355.5 Kcal, which bridged the deficiency of energy requirements of the children. Furthermore, the flour that was used was full fat and therefore this contributed to the increased energy content considering that fats are energy dense. Energy density is one of the important determinants of the nutritional adequacy of diets fed to children. Energy is required by children for proper growth and development, and deficiency in energy intake has been implicated for poor growth in children [29]. Foods supplements that have been shown to have energy content of more than $1.0 \mathrm{~g} / 100 \mathrm{~g}$ has been shown to reduce the prevalence of wasting and underweight in malnourished children [6]. This could have been the reason for improved nutritional status of children.

Table 3. Prevalence of wasting between baseline and 9 months.

\begin{tabular}{|c|c|c|c|c|c|c|c|}
\hline \multirow{2}{*}{$\begin{array}{l}\text { (Wasting) } \\
\text { Experimental groups }\end{array}$} & \multicolumn{2}{|c|}{ Before intervention (Baseline) } & \multicolumn{3}{|c|}{$6^{\text {th }}$ month } & \multicolumn{2}{|l|}{$9^{\text {th }}$ month } \\
\hline & SM group & SMS group & MZ group & SM group & SMS group & SM group & SMS group \\
\hline$<-2$ SD to -3 SD (Moderate) & 4.6 & 5.9 & 5.9 & 3.4 & 4.6 & 3.9 & 4.8 \\
\hline$<3 \mathrm{SD}$ (Severe) & 1.2 & 0.2 & 0.2 & 0.4 & 0 & 0 & 0 \\
\hline
\end{tabular}

$\mathrm{SM}=$ soybean + maize, $\mathrm{SMS}=$ sorghum + maize + soybean, $\mathrm{MZ}=$ maize only

Results show that there in the CSB group, there was significant reduction in the prevalence of wasting, underweight and stunting. In the SMS group, there was a significant reduction in the prevalence of underweight and wasting only (table 2 ).

Table 4. 3 Nutritional status of the children by $Z$ scores at baseline and $9^{\text {th }}$ month.

\begin{tabular}{|c|c|c|c|c|c|c|c|}
\hline \multirow{2}{*}{ Porridge type } & \multirow{2}{*}{ Nutrition index } & \multicolumn{2}{|l|}{ Baseline } & \multicolumn{2}{|l|}{$6^{\text {th }}$ month } & \multicolumn{2}{|l|}{$9^{\text {th }}$ month } \\
\hline & & Mean \pm SE & F value & Mean \pm SE & F value & Mean \pm SE & F value \\
\hline \multirow[b]{2}{*}{ SM } & WAZ (Underweight) & $-0.757 \pm 0.075$ & $\begin{array}{l}F=1.862 \\
d f=2.169 \\
P=0.175\end{array}$ & $0.076 \pm 0.09$ & $\begin{array}{l}F=2.90 \\
d f=1.867 \\
p=0.256\end{array}$ & $0.134 \pm 0.07$ & $\begin{array}{l}0.267 \pm 0.02 \\
\mathrm{df}=1.456\end{array}$ \\
\hline & WHZ (Wasting) & $-0.349 \pm 0.071$ & $0.234 \pm 0.016$ & $0.234 \pm .0453$ & $\begin{array}{l}\mathrm{F}=3.23 \\
\mathrm{df}=1.867 \\
* \mathrm{P}<0.05\end{array}$ & $0.378 \pm 0.002$ & $\begin{array}{l}\mathrm{F}=6.45 \\
\mathrm{df}=1.456 \\
* \mathrm{P}<0.002\end{array}$ \\
\hline \multirow{3}{*}{ SMS } & WAZ (Underweight) & $-0.674 \pm 0.983$ & $\begin{array}{l}F=2.560 \\
d f=2.169 \\
p=0.345\end{array}$ & $0.156 \pm 0.057$ & $\begin{array}{l}\mathrm{F}=1.890 \\
\mathrm{df}=1.867 \\
* \mathrm{P}<0.05\end{array}$ & $\begin{array}{l}1.345 \pm \\
0.02\end{array}$ & $\begin{array}{l}\mathrm{F}=1.345 \\
\mathrm{df}=1.365 \\
* \mathrm{P}<0.001\end{array}$ \\
\hline & WHZ (Wasting) & $-0.237 \pm 0.067$ & $\begin{array}{l}F=1.987 \\
d f=2.169 \\
p=0.289\end{array}$ & $1.89 \pm 0.002$ & $\begin{array}{l}\mathrm{F}=2.78 \\
\mathrm{df}=1.867 \\
*_{\mathrm{p}}=0.045\end{array}$ & $\begin{array}{l}2.476 \pm \\
0.023\end{array}$ & $\begin{array}{l}\mathrm{F}=\quad 3.423 \quad \pm \\
0.067 \\
* \mathrm{P}=0.045\end{array}$ \\
\hline & MUAC & $12.3 \pm 1.45$ & $\begin{array}{l}F=2.46 \\
d f=2.169 \\
p=0.384\end{array}$ & 13.0 & $\begin{array}{l}\mathrm{F}=2.890 \\
\mathrm{df}=1.867 \\
*_{\mathrm{p}}=0.05\end{array}$ & 13.52 & $\begin{array}{l}\mathrm{F}=2.89 \pm 0.056 \\
\mathrm{P}<0.03\end{array}$ \\
\hline
\end{tabular}

$\mathrm{SM}=$ soybean + maize, $\mathrm{SMS}=$ sorghum + maize + soybean, $* \mathrm{p}<0.05$ significant 


\section{Conclusion}

This study showed that fortification of commonly consumed cereal, maize and sorghum, with soybean improved the nutrient adequacy of the diet, which in turn led to improved nutritional status of the children. Utilization of high protein legumes such as soybean can be one of the sustainable ways of reducing the prevalence of malnutrition in developing countries. This is with reference to climate change, where the production costs of animal source foods is expected to increase.

\section{Recommendation}

Policies on fortification of commonly consumed staples in Western Kenya with soybeans to improve the nutritional adequacy of the diets of the children should be made. This is to augment the efforts of the County Early Childhood Education Bill that advocates for feeding of pre-school children with nutritionally adequate foods. Furthermore, as one of the ways of reducing the prevalence of malnutrition among pre-school children in Western Kenya, awareness of the nutritional benefits of soybean should be raised to increase its adoption and therefore consumption in the households. This can be done though nutrition education programs in the study area. Polices in the agricultural sector should be geared towards improving the production of soybean in the study area.

\section{Acknowledgement}

This research was made possible through funding from MU-K_ VLIR-UOS AGBIO PROJECT.

\section{References}

[1] UNICEF/WHO/World Bank (2015) Levels and trends in child malnutrition. UNICEF-WHO-World Bank group joint child malnutrition estimates. Key findings of the 2015 edition. Retrieved on $6^{\text {th }}$ August, 2016 from http://unnicefmalnutritionestimates.org

[2] World Hunger Education Service (2015) World Hunger and Poverty Facts and Statistics. Accessed on $8^{\text {th }}$ August, 2016 from http://www.worldhunger.org/articles/Learn/world\%20hunger $\% 20$ facts $\% 202002$.htm

[3] UNICEF (2013) Improving child Nutrition: The achievable imperative for global progress. Accessed on $10^{\text {th }}$ June, 2016 from www.unicef.org/publications/index.html

[4] FAO (2015) The state of food insecurity in the world. Food and Agriculture Organization of the United Nations, Rome. http://www.fao.org/docrep/013/i11683e/i1683e.pdf. Accessed 15th June, 2016.

[5] Hoffman JR, Falvo MJ (2004) Protein - which is best? Journal of Sports Science and Medicine.3: 18-130.

[6] Michaelsen KF, Floppe C, Root N, Kaestel P, Stougard M, Laurtzen L, Molgard C, Girma T, Friis H (2009)Choice of food ingredient for moderately malnourished children 6 month to 5 years of age. University of Copenhagen, Denmark. Journal of Food and Nutrition 30: 1-62.

[7] Shiriki D, Igyor, MA, Gernah DI (2015) Nutritional evaluation of complementary food formulations from Maize, Soybean and Peanut Fortified with Moringa oleifera Leaf Powder. Food and Nutrition Sciences. 6: 494-500.

[8] Swick R (2007) Selecting soy protein for animal feed. $15^{\text {th }}$ annual ASA-IM South East Asian feed technology and nutrition workshop. ASA-IM, Singapore. Pp 1-11.

[9] Kolapo AL (2011) Soybean: Africa's potential Cinderella Food Crop. Ibadan: Nigeria.

[10] Akomo PO, Egli I, Okoth MW, Bahwere P, Cercamondi CI, Zeder C, Njage PMK, Owino VO (2016) Estimated Iron and Zinc Bioavailability in Soybean-Maize-Sorghum Ready to Use Foods: Effect of Soy Protein Concentrate and Added Phytase. Journal of Food Processing \& Technology. 7: 556.

[11] Government of Kenya (2014) The County Early Childhood Education Bill 2014. Kenya Gazette Supplement No. 108.

[12] FAO (2003) Food energy - Methods of analysis and conversion factors. Food and Agriculture organization Nutrition paper 77 .

[13] Onoja US, Akubor PI, Gernar DI, Chinmma EC (2014) Evaluation of complementary food formulated from local staples and fortified with calcium, iron and zinc. Journal of Nutrition and Food Science. Vol 4(6): 1-6.

[14] de Onis M, Onyango AW, Van den Broeck J, Chumlea WC, Martorell R (2004) Measurement and standardization protocols for anthropometry used in the construction of a new international growth reference. Food Nutr Bull. 25: S27-S36.

[15] Kenya National Bureau of Statistics (KNBS) \& ICF Macro (2015) Kenya Demographic and Health Survey 2014-2015. Calverton, Maryland: KNBS and ICF Macro.

[16] Grant F, Cole D, Kirimi S, Levin C, Garret D, Kariuki, S, Ouedarugo, H, Loechi, C. et al, (2016) Prevalence of Vitamin A deficiency among infants participating in the Mama Sasha proof of concept project in Western Kenya.

[17] Standing committee on Nutrition (2016) An assessment of the situation regarding the principle of "ensuring that no one is left behind" at the global level: The United Nations System Standing Committee on Nutrition. Accessed on $2^{\text {nd }}$ February, 2016 from https://sustainabledevelopment.un.org/index.php?page=view\& type $=30022 \& n r=120 \&$ menu $=3170$

[18] Dewey KG, Begum K (2011) Long-term consequences of stunting in early life. Maternal and Child Nutrition, 7(Suppl. 3), $5-18$

[19] Waswa M, Keding BG, Irmgard J, Johannes H, Michael, BK (2015) Nutritional status, dietary diversity and morbidity among infants and children aged 6-23 months in rural western Kenya. Retrieved on $15^{\text {th }}$ July 2016 from http://www.bioversity.org

[20] Stephenson K, Amthor R, Mallowa S, Nungo R, MaziyaDixon B, Gichuki S, Mbanaso A, Manary, M(2010) Consuming cassava as a staple food places children 2-5 years old at risk of inadequate protein intake, an observational study in Kenya and Nigeria. Nutrition Journal 9: 9. 
[21] Bisimwa G, Owino VO, Bahwere P, Dramax M, Donned P, Dibari F, Collins S (2012) Randomized controlled trial of the effectiveness of a soybean-maize-sorghum-based ready-to-use complementary food paste on infant growth in South Kivu, Democratic Republic of Congo. American Journal of Clinical Nutrition. 95: 1157-64.

[22] Were GM, Ohiokpehai O, Okeyo-Owuor JB, Mbagaya GM, Kimiywe J, Mbithe D, \& Okello MM (2010) Soybean (Glycine max) complementation and the zinc status of HIV and AIDS affected children in Suba District, Kenya. AJFAND. (3): 2187-2202.

[23] Kamau J, Ohiokpehai O, Mbithe D, Kimiywe J, Oteba L, Were GM, King'olla B (2008) Effect of soybean (Glycine max) Supplementation on nutritional status of school children aged 6-9 years from HIV affected households in Suba District, Kenya. MSc thesis. Kenyatta University.

[24] Niyibituronsa M, Kyallo F, Mugo N, Gaidashova S (2014) Improving the nutritional status of malnourished children using soybean products in Rwanda. African Journal of Food, Agriculture and Development. Vol. 14 (4).
[25] Kamau EH, Serrem CA, \& Wakhu-Wamunga F, (2014) Nutrient composition, Efficacy and Consumer acceptability of soy fortified complementary foods from Western Kenya. Department of Family and Consumer Science, University of Eldoret.

[26] Serrem CA, de Kock HL, Oelofse A, Taylor, JRN (2011) Soy fortified sorghum biscuits for supplementary feeding of school-age children. Department of Food Science, University of Pretoria.

[27] Solomon M (2005) Nutritive Value of Three Potential Complementary Foods Based on Cereals and Legumes. The African Journal of Food, Agriculture, Nutrition and Development (AJFAND). 5: 1-14.

[28] Kismul H, Broeck JV, Lunde TM (2014) Diet and kwashiorkor: a prospective study from rural DR Congo. Peer J 2: e350; DOI 10.7717/peerj.350.

[29] Food and Agriculture Organization of the United Nations (2011) Protein digestibility and absorption: Effects of fibre and the extent of individual variation. Retrieved on $23^{\text {rd }}$ July, 2016 from www.fao.org. 